Article

\title{
Redesigning Terraced Social Housing in the UK for Flexibility Using Building Energy Simulation with Consideration of Passive Design
}

\section{Hasim Altan ${ }^{1,2, *}$, Nicola Gasperini ${ }^{3}$, Sam Moshaver ${ }^{4}$ and Antonio Frattari ${ }^{3}$}

1 Sustainable Design of the Built Environment, Faculty of Engineering \& IT, British University in Dubai, Dubai 345015, UAE

2 Welsh School of Architecture, Cardiff University, CF10 3NB Cardiff, UK

3 Department of Civil, Environmental and Mechanical Engineering, University of Trento, Trento 38123, Italy; E-Mails: nicola.gasperini@gmail.com (N.G.); antonio.frattari@unitn.it (A.F.)

4 School of Architecture, Faculty of Environmental Design, University of Montreal, Montreal, QC H3C 3J7, Canada; E-Mail: smoshaver2000@yahoo.com

* Author to whom correspondence should be addressed; E-Mail: hasim.altan@buid.ac.ae or hasimaltan@gmail.com; Tel.: +971-4-279-1448; Fax: +971-4-279-1490.

Academic Editors: Masa Noguchi and Marc A. Rosen

Received: 16 February 2015 / Accepted: 24 April 2015 / Published: 5 May 2015

\begin{abstract}
A chosen case study house forms the basis of this paper, which is a pilot energy-efficient social housing project, completed by one of the largest housing developers in the UK. The main aim of this study is to inform the redesign of flexible energy-efficient housing units. The housing, designed for social tenants, was built by the Accent Group in 2005, using modern construction methods and sustainable materials, based on extensive research from the adaptable and "Grow Home" principles of Avi Friedman as well as open building implementation. The first pilot scheme was designed in collaboration with the Building Energy Analysis Unit at the University of Sheffield, together with the Goddard Wybor Practise, and was a successful housing development with respect to being environmentally friendly and a low-energy design scheme for the UK climate. This paper presents redesigning of flexible terraced housing units, and their performance evaluation, using a building simulation method as well as the passive-house planning package. The aim was to plan a row of terraced houses that can not only utilize a flexible design concept in floor planning layout, but also to reduce energy consumption with a passive design with particular attention paid to material selection. In addition, building simulation work has been
\end{abstract}


carried out with the use of DesignBuilder software for both thermal and energy performance evaluation. The study examines the annual energy performance and comfort conditions in the designed house to be situated in the Northeast of England, UK. A terraced house unit design is considered a flexible home that can adjust to the needs of different tenants for the purpose of achieving a sustainable building under different aspects, such as low energy, low carbon, use of renewables, and low impact materials, with flexibility by design.

Keywords: flexible housing; sustainable design; energy efficiency; social housing; building simulation; mass customization; passive design

\section{Introduction}

Climate change is one of the biggest issues the world is facing today and the UK government is at the forefront to deal with this challenge. The domestic sector accounts for $27 \%$ of the UK's carbon emissions, making it necessary to pay attention to the way homes are designed and constructed [1]. Attention should also be given to making the existing housing stock energy efficient, as most of them will continue to be in existence for another 50 years, if not longer. According to the UK House of Commons Environment Committee, around 200,000 dwellings would need to be built each year in England, up to 2016, between 1991 and 2016, as there is a need for 4.4 million houses to be added to the housing stock [2]. According to the English Housing Survey [3], around 19\% of the dwelling stock is flats; most of these are purpose built low-rise flats. The most common types of dwellings are terraced houses $(29 \%)$, followed by semi-detached houses (26\%). This was also stated in a report by the Office for National Statistics (ONS), which is the executive office of the UK Statistics Authority [4]. As the largest portion of homes in the country, it makes the existing terraced housing schemes not only a priority case for refurbishment and/or retrofit, but also offers a very good opportunity for redesign, to upgrade and/or improvement sustainability in the future.

The introduction of flexibility into the living space is the solution for users to adjust successfully to social behavioral changes. The Oxford dictionary describes the word "flexibility" as follows: "capable of bending easily without breaking" and "able to be easily modified to respond to altered circumstances or conditions" (Oxford 2015) [5].

Flexible architecture is described by Lelieveld [6] as follows:

"The term flexible architecture describes an architecture from which specific components can be changed in response to external stimuli, for example the users or environment. This change could be executed by the building system itself, transformed manually or could be any other ability to transform by an external force" [6] and [7] (p. 1).

The need for change is a universal phenomenon, and flexibility in the quality characteristics of a space accommodates spatial changes over a long period of time, rather than just thinking of the needs for present use of the space [8]. Furthermore, incorporating flexibility into the design can accommodate various functional demands within a limited space (economic benefit). In addition to its pragmatic benefits, flexible housing has good ecological potential, especially with regard to conserving energy and resources [9]. The refurbishment, obsolescence, and demolition of flexible designs require less material, 
energy, and labor, and, therefore, it is sustainable by design since there are less waste and lower costs (environmental benefit) associated with the process [10].

\subsection{Flexible Housing}

In the past few decades, architectural practice has faced a lot of challenges. Although our living conditions change in different contexts considering social, technological, economic, environmental, and political aspects, our housing types, responding to our patterns of living evolution, are still largely based on early 20th century models [11]. The speed of modernization, which started in the 18th century, is changing our lives, and the industrial revolution has made it so difficult for buildings to function without any flexibility, due to the changes in our lifestyle. Because of the mass migration of people from villages to cities, creating metropolises, social disorder, due to poor quality of living, has emerged and expanded because of new technology [12].

The architecture of flexibility can be considered one of the most important achievements of the Modern Movement [13]. This approach aimed to help dwellers change their living spaces with minimal costs; avoid expensive and destructive alterations; change their habits; and avoid being forced to move from their homes [14].

Schneider and Till in their paper "Flexible Housing; Opportunities and Limits" (2005), described flexible housing as "housing that is designed for choice at the design stage, both in terms of social use and construction, or designed for change over its lifetime" [15] (p. 157). There is a great need for studying flexibility of our living space with the potential of spatial changes over long periods of time rather than only thinking of the need of space for the present use. Architects and homebuilders need to surpass the phrase of "form follows function" in time and space.

\subsection{Support, Infill and Open Building}

N. John Habraken, a Dutch architect, educator, and theorist (1976) [16], employed the theory of the hierarchical principle of subsystems as one of the basic concepts of flexible housing. The essence of Habraken's theory is that, in housing, the role of community and the role of the individual are distinct. Habraken believed in reestablishing the dweller as an active participant in the total process of housing, and he developed a methodology for linking the processes of products and decisions to their technical implementation [16-19].

The division of "infill" and "support" was initially explored by Habraken, wherein, he explained support as the permanent part of a building provided to the occupant by the builder or the architect commissioned; while infill includes the interior partitions, a kitchen, and bathrooms as defined by the occupant. The systems and parts associated with the infill level tend to change in cycles of 10 to 20 [17,19]. These transformations may be occasioned by the occupants' changing requirements or preferences; by the cyclical need for technical upgrades; or by changes in the base building (support) [19]. The open building (OB) implementation approach is the continuation of Habraken's approach, elaborating more on practical aspects, design, and construction [10].

In this paper, a case study of a pilot terraced energy-efficient social housing unit (Figure 1) has been chosen, with the main aim being to inform the redesign of flexible energy-efficient housing units. The housing was designed for social tenants, and built by the Accent Group in 2005 using modern methods 
of construction (MMC), and sustainable materials based on extensive research from the "adaptable" and "grow home" principles of Avi Friedman [20]. The first pilot scheme was designed in collaboration with the Building Energy Analysis Unit (BEAU) at the University of Sheffield [21] together with architects at the Goddard Wybor Practise (GWP) Ltd. The project was a successful housing development. Being both environmentally friendly and a low energy design scheme for the UK climate.

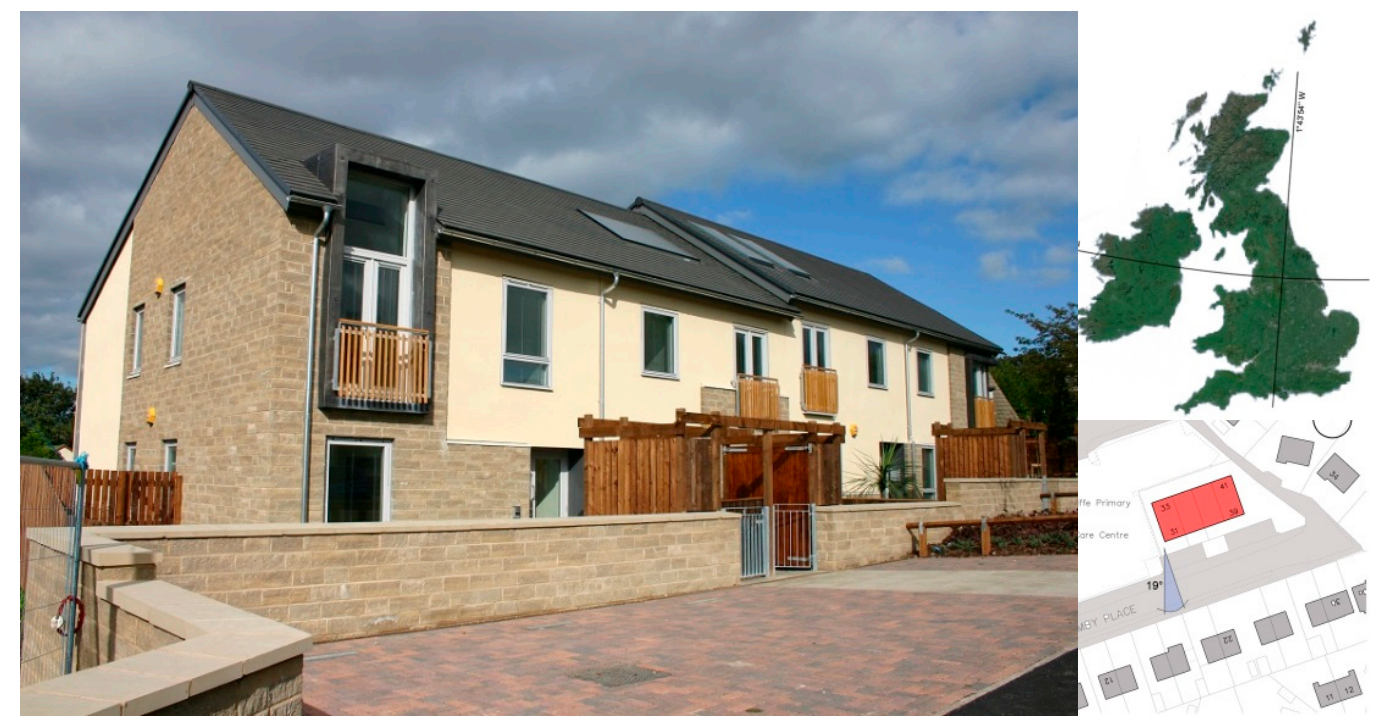

Figure 1. A row of terrace houses_-energy efficient social housing in northeast England, UK.

This paper presents the redesign of terraced housing units [22] and their energy performance evaluation, using building simulation together with support from a passive-house planning package. The aim is to plan a row of terraced houses that can utilize a flexible design concept as well as building performance evaluation for optimizing energy demand and planning of passive design. Moreover, the terraced house design is considered a flexible home that can be adjusted the tenants' different needs, with the purpose of achieving sustainability with respect to different aspects, such as low energy, low carbon, use of renewables and low impact materials, with flexibility by design. This project focuses on the flexible design of infill (interior of unit). Furthermore, it compares the performance evaluation of the flexible floor plan layout and the traditional existing layout.

\section{Approach, Methodology and Analysis}

\subsection{Early Design Stage}

The case study chosen for the studies in this paper goes back to the "Accent Home" concept, a terraced house design for social housing, developed and situated in Leeds/Bradford region in the northeast of England. The building design was completed by one of the UK's largest social housing developers at the time to achieve low cost and low energy designs for the UK social housing sector.

The aim of this study was to design a new sustainable building prototype situated in the same area as the Accent Home; beginning from the early stages of architectural design, together with a vision to develop future housing with flexibility in mind, to meet the needs of different tenants or the needs of a single family in the future. Going back to the drawing board, all dimensions of each apartment have been 
considered. On an overall plan of $290 \mathrm{~m}^{2}$, there are four apartments (i.e., units); each one a rectangular plan of $12 \mathrm{~m}$ (north-south direction) $\times 6 \mathrm{~m}$ (east-west direction). The inclination of $19^{\circ}$ to the east is to maximize the sunshine in the morning as opposed to the afternoon. Moreover, solar analyses have been conducted because of the importance of sun and its directions from different periods in a typical year as well as the size and length of shading devices to avoid excessive solar gains during the summer period (Figure 2a,b).

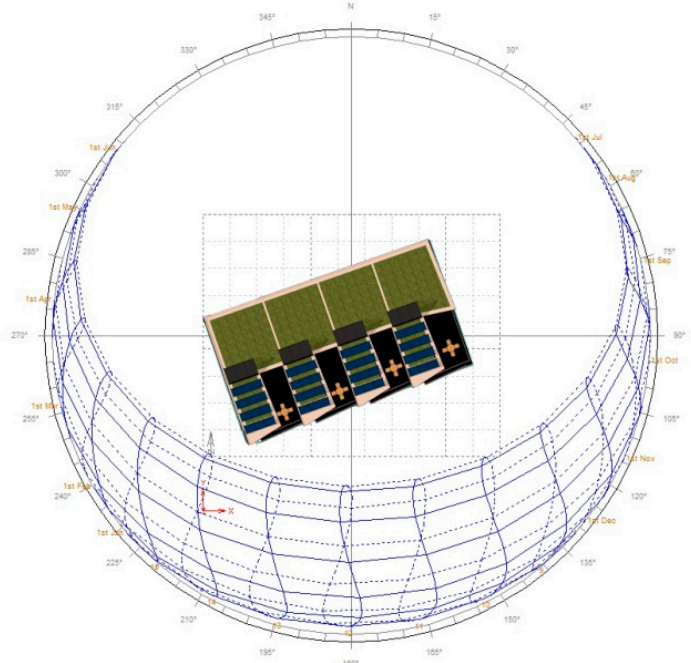

(a)

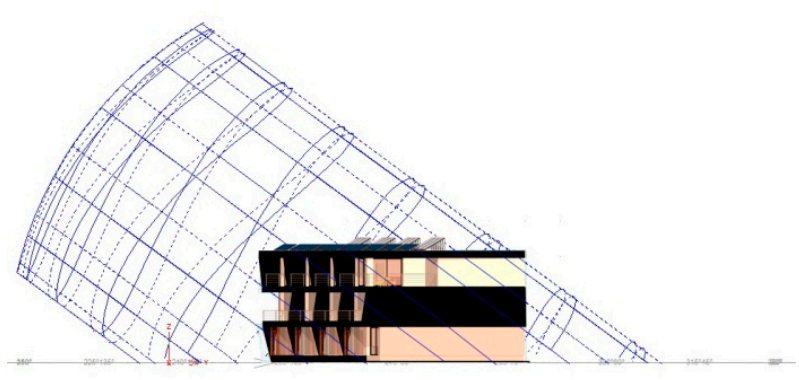

(b)

Figure 2. Annual sun path: top view (a); east front (b).

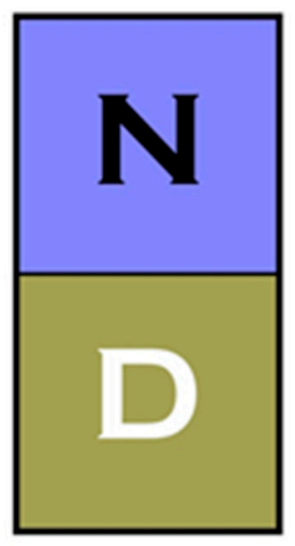

(a)

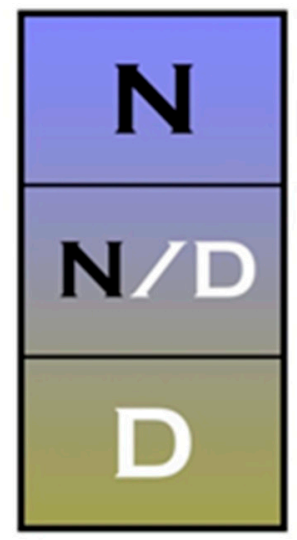

(b)

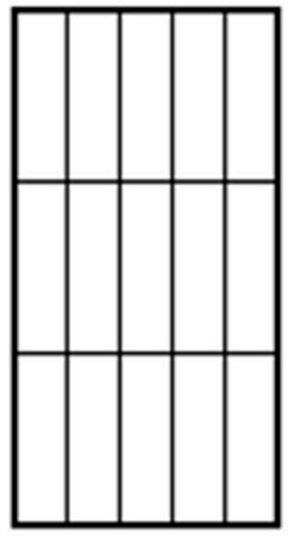

(c)

Figure 3. Layout and configuration (N: Night, D: Day).

After studying the history of terraced houses in England (UK) and considering design flexibility, the design started to take a different configuration that could arrive at the goal of flexibility, while at the same time be energy efficient, before finally arriving at the chosen layout $[15,22]$.

As mentioned earlier, the main facade of the building is oriented $19^{\circ}$ to the east and the extended plan is in the shape of a rectangle $(12 \mathrm{~m} \times 6 \mathrm{~m})$. First, a decision has been given to divide the plan into two different square areas: Day (D) and Night (N) (Figure 3a,b). The Day area is suitable for daily activities, due to natural light and solar gains coming from the south direction. On the other hand, the Night area is situated at the north side of the house, which is perfect for nightly activities that do not require too much 
light (Figure 3a). The first division of the apartment into two different areas was too straight for future movement of the building interior space. Dividing the length into three different areas allowed defining a third space in between, so that this could be used for both daily and nightly activities. This new space can be called "Flexible Space" or "Margin", also named by Habraken, "adaptability" (Figure 4b) [16]. The short side of the apartment needed a division that could take into account all the different aspects of the house elements, such as stairs, doors, furniture, appliances, etc. A $120 \mathrm{~cm}$ module (i.e., a full module) is used to fit every element into a regular grid. For example, a half module $(60 \mathrm{~cm})$ is enough for a kitchen space with furniture and appliances; a 2/3 module $(80 \mathrm{~cm})$ is enough space for doors and a single bed; and a full module $(120 \mathrm{~cm})$ is enough space for stairs and sliding doors (Figure $3 \mathrm{c}$ ).

The positioning of the staircase and washroom is an important decision that would define all the following phases of a flexible design. These are, in effect, two inflexible elements that once placed cannot be easily moved. For this reason, decision of situating the staircase in the north side of the building, instead of the washroom, needed accurate analysis. The washroom in the back might have an external window that would also allow natural ventilation. On the other hand, the stairs in that position creates an independent nucleus and a new entry to the building, and to each independent level of the building. This was considered the most flexible solution (Figure 4).

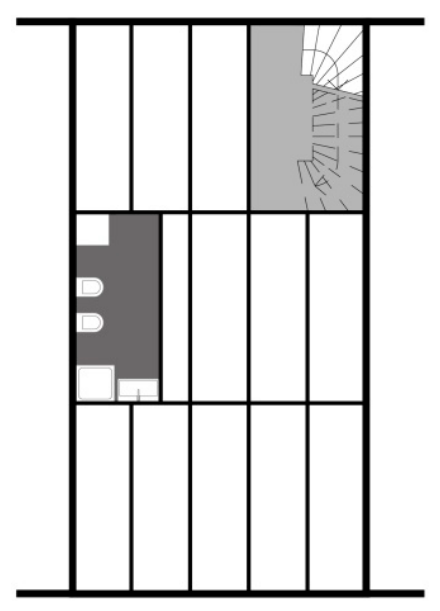

(a) ground floor

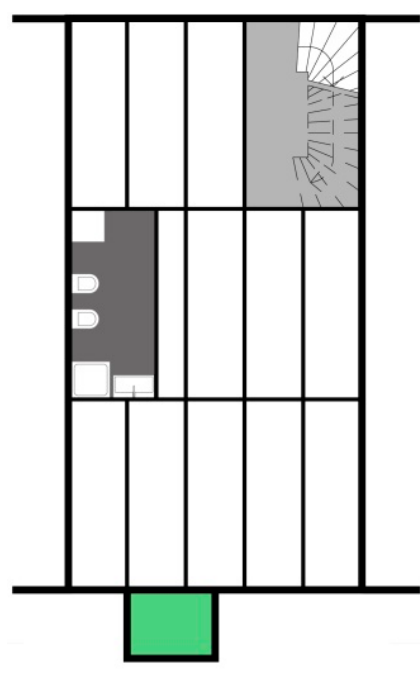

(b) first floor

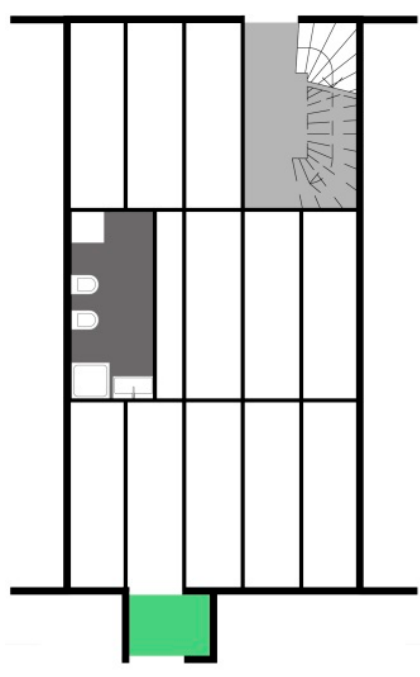

(c) second floor

Figure 4. Positioning of continues staircase and toilettes on all three floor plans.

Furthermore, the stairwell can be used for natural ventilation inside the building and can create a natural solar chimney (Figure 5a). As a consequence, the bathroom found the right arrangements at the opposite side of the central area. In this particular situation, an inflexible space such as the bathroom, helped to create a distinct division of the apartment into three different areas, and at the same time, the possibility of considering all the remaining spaces as unique zones (Figure 4b).

The positioning of the main entry is another important problem to be solved in a flexible design and, moreover, in a terraced home. First, the main entry has a double function, i.e., it is entranceway from the main street and is also a space that can be used as a temporary deposit, and a small greenhouse in the wintertime. Moreover, the off-center position permits the creation of two spaces, for big and small windows, a solution that allows a division of the interior space in the future. The distance from the 
partition wall permits solar rays coming from the east to reach the big window of the preceding apartment (Figure 4c).

Due to the main entry and the staircase disposition, the apartment is provided with two independent entry doors. The first one on the south facade and connected directly with the main street, and the second one on the north side that can be used as a service door or an independent door to arrive at the apartments of the first and second floors. The internal space resulting from this division is a long and dynamic space of $48 \mathrm{~m}^{2}$ that can meet the needs of different tenants (Figure $5 \mathrm{a}$ ).

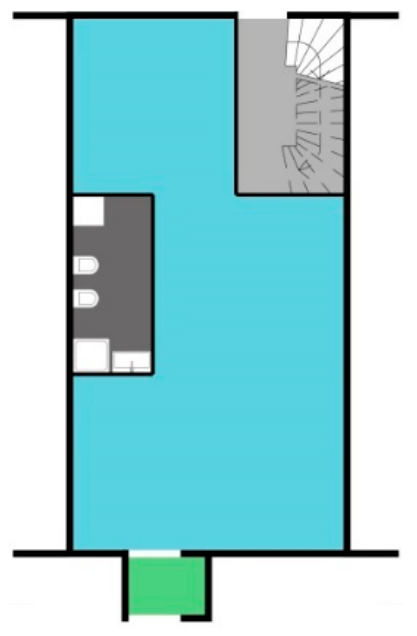

(a) first floor

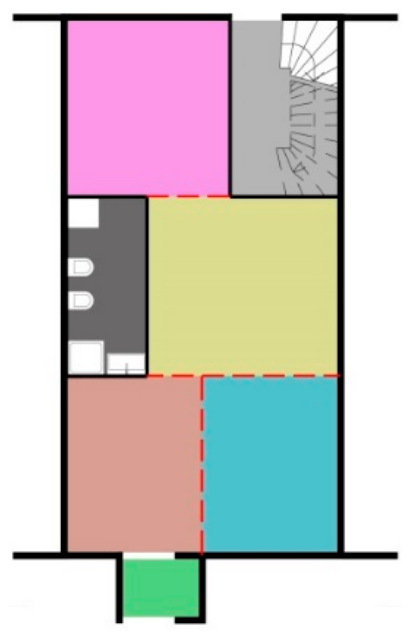

(b) second floor

Figure 5. Spaces with possible divisions on upper floors.

Figure 5 shows a top view of the space, with possible divisions. Tenants can convert different zones using sliding walls, i.e., sliding walls for daily changes or through more or less flexible walls (Figure 5b).

Figure 6 is the social housing development pilot project as a row of terraced houses, which has been redesigned with flexibility, to meet the needs of different tenants including, single-family users in the future.

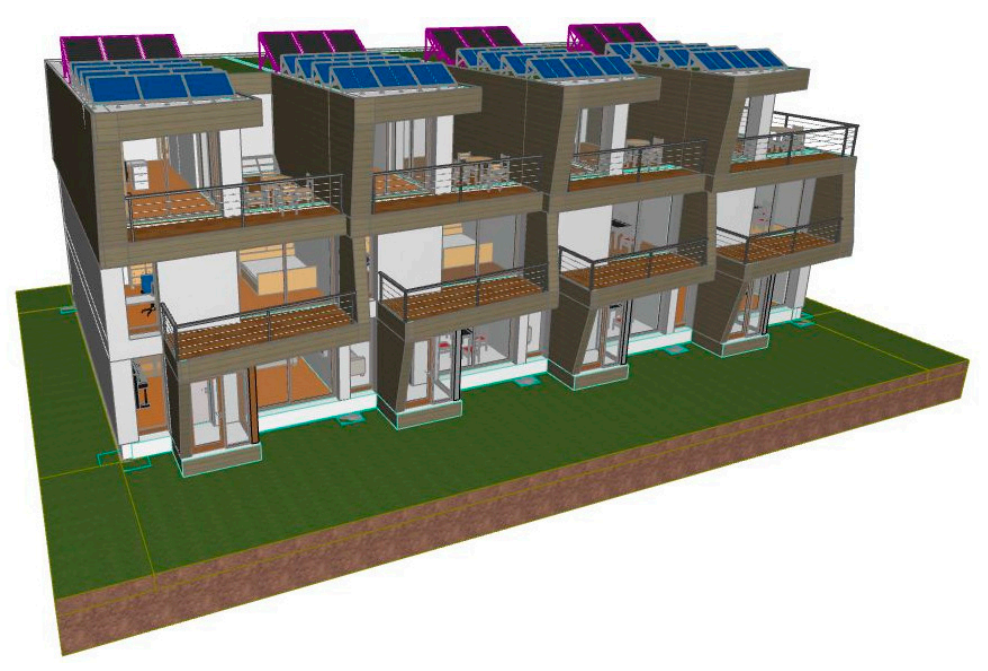

Figure 6. Redesign of a social housing development. 
The division of infill and support was initially explored as one of the main principles of flexible housing. This division support is the permanent part of the building provided to the occupant by the builder or the architect commissioned, while infill includes the interior partitions, for example a kitchen and bathrooms, as defined by the occupant. The systems and parts associated with the infill level tend to change in cycles of 10 to 20 years [16], whereas the support has a 100-year lifespan. These transformations may be occasioned by the occupants' changing requirements or preferences, by the cyclical need for technical upgrades, or by changes in the base building (support). In this project, the clear span of floor plan is proposed as the support, whereas the infill (interior partition) is being customized gradually.

Seeing the possible divisions (i.e., configuration layouts) (Figure 5a,b) and the longitudinal section (Figure 7), helps to understand the way in which the housing units can grow over their lifespan. Starting from a configuration with one unit, i.e., first and second floor units (Figure 5a,b), it is possible to divide the same housing unit into two or even three separate units (Figure 8, left to right).

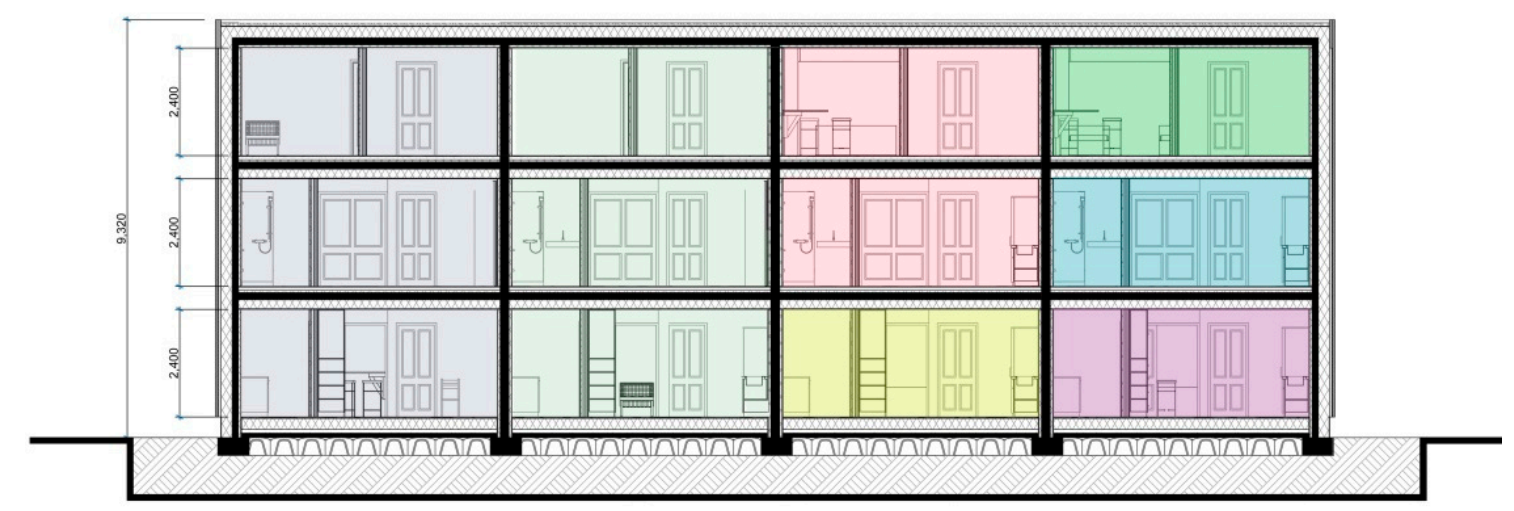

Figure 7. A longitudinal section with growing units.

The internal space resulting from the division is a long and dynamic space of $48 \mathrm{~m}^{2}$ that can meet the needs of different tenants. In addition, Tenants can convert different zones through sliding walls, or through more or less flexible walls. In the following, the full layouts of the housing units' floor plans are presented (Figure 8).

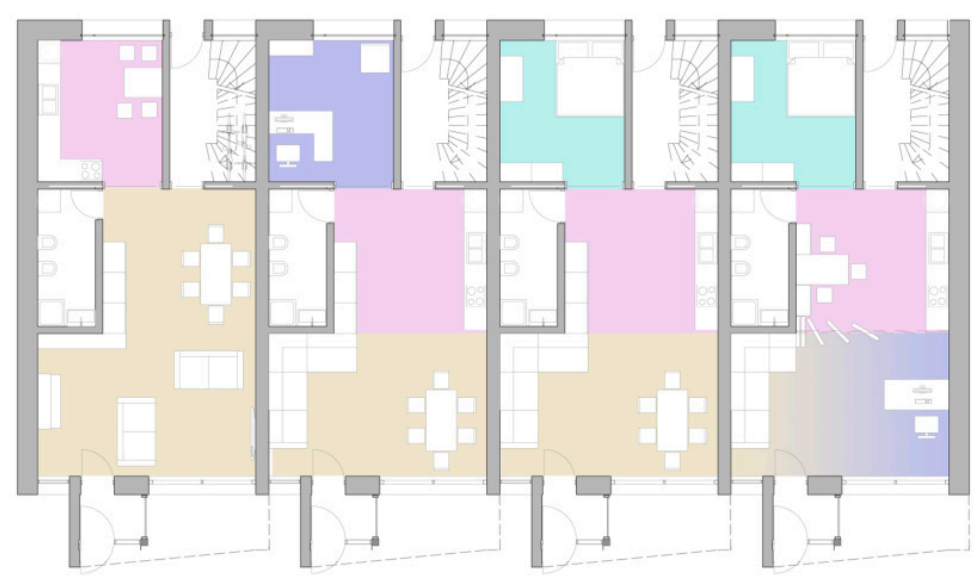

Ground Floor

Figure 8. Cont. 

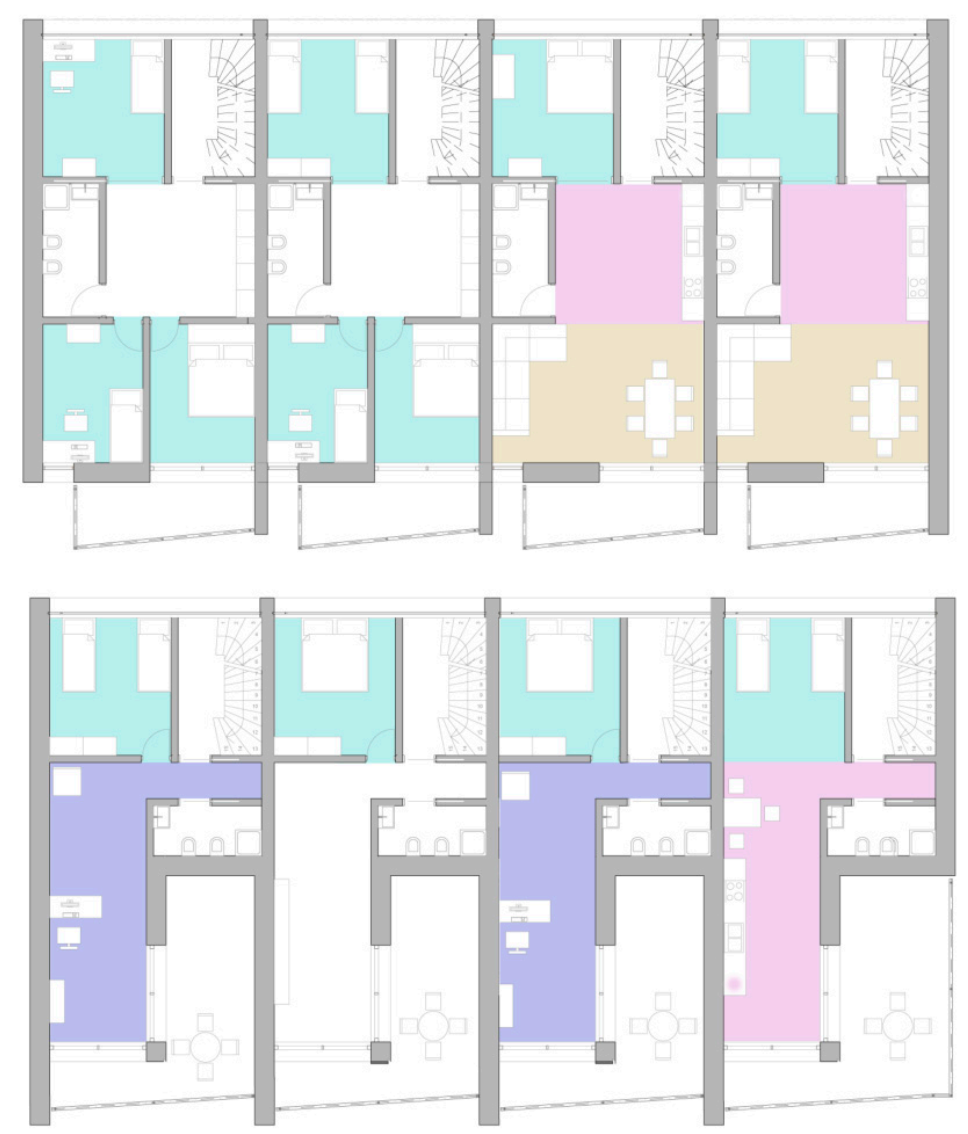

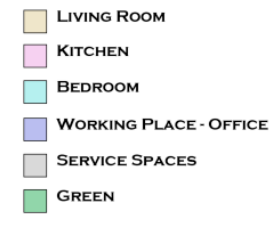

First Floor

Second Floor

Figure 8. Floor plans of the housing units.

\subsection{Passive House Planning}

Energy efficiency in housing is an important factor that has to be considered in order to achieve the aim of sustainable housing. Thus, in recent years, the applications of renewable energy in buildings has rapidly increased; sometimes supported by national subsidies. Nevertheless, the high costs of energy systems and their complex integration, coupled with expensive upkeep, discourages many people from investing in such systems. It is important to design flexible houses in order to advance the use of new technologies; however, it is equally necessary to reduce the use of energy systems by maximizing the advantages of the sun's energy, location and materials. This is a passive method that allows comfort with few energy systems.

Sustainable building, through the Passivhaus standard [23], can be achieved at any location in the world. Passive houses are very well insulated and draught-proofed buildings whose annual space heat demand is so low that a conventional heating system can be omitted. The small amount of heat still required can be delivered to individual rooms by heating the air supplied through the ventilation system. This occurs when the space heating energy demand is not more than that of $15 \mathrm{kWh} / \mathrm{m}^{2}$ per annum [23].

Super insulation, isolated thermal bridges and airtightness are three important principles of the Passivhaus standard that have to be considered during every design stage. In this flexible and passive house design study, there are low u-values [24] (i.e., thermal conductivity or heat transfer coefficient-a measure of heat loss in a building element such as a wall, floor or roof); windows with u-values of 
$0.77 \mathrm{~W} / \mathrm{m}^{2} \mathrm{~K}$, external walls with $\mathrm{u}$-values of $0.11 \mathrm{~W} / \mathrm{m}^{2} \mathrm{~K}$, a roof with a $\mathrm{u}$-value of $0.11 \mathrm{~W} / \mathrm{m}^{2} \mathrm{~K}$, and a ground floor with a u-value of $0.12 \mathrm{~W} / \mathrm{m}^{2} \mathrm{~K}$, which can noticeably reduce the heat transfers.

In the case study home, a combination of the planning principles from the "plotter pen" [23] and a cross-laminated timber structure to avoid thermal bridges through the building boundary has been considered (see Figure 9).

The following section (Figure 9) shows the planning principle from the plotter pen. This principle is used in the design of a passive house, and in particular in sections and in floor plans. The width of a plotter pen corresponds to a heat transmission resistance of $\mathrm{R}=6 \mathrm{~m}^{2} \mathrm{~K} / \mathrm{W}$. In this case, the following equation is used:

$$
R=\frac{s}{\lambda}
$$

where $\mathrm{R}$ is the thermal resistance, $\lambda$ is the thermal conductivity ( $\mathrm{u}$-value), $\mathrm{s}$ is the thickness of an insulation material with thermal conductivity value of $0.043 \mathrm{~W} /(\mathrm{mK})$ (wood soft fiber). In the study, a scale width of $25.8 \mathrm{~cm}$ is approximated at $25 \mathrm{~cm}(0.25 \mathrm{~m})$. If the outer shell (red insulation layer in Figure 10) manages to wrap the envelope surrounding the whole building with full width and without any interruption, the project can avoid thermal bridges (except for more detailed analysis).

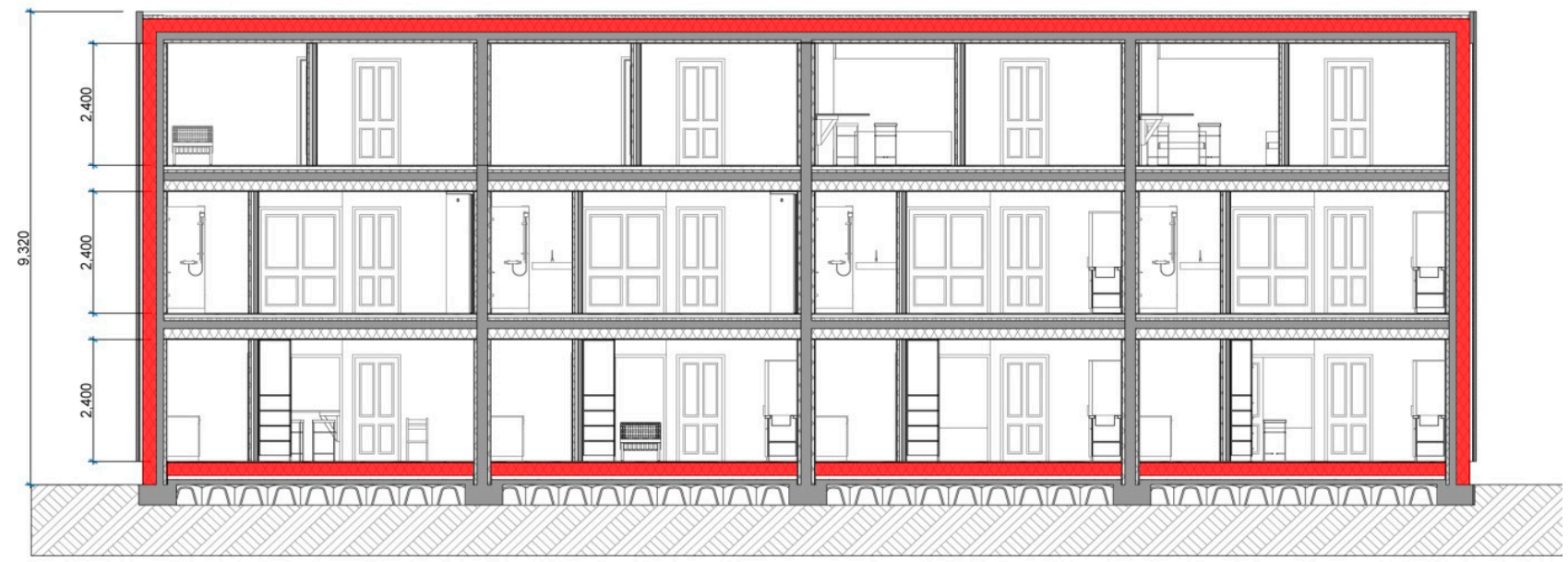

Figure 9. Planning principle from the "plotter pen" in east-west section.

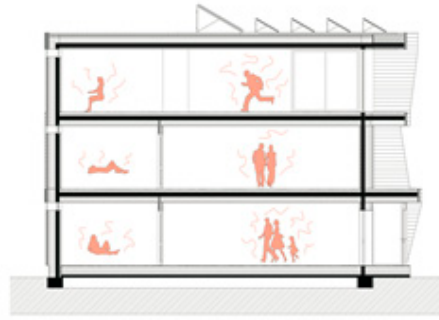

(a)

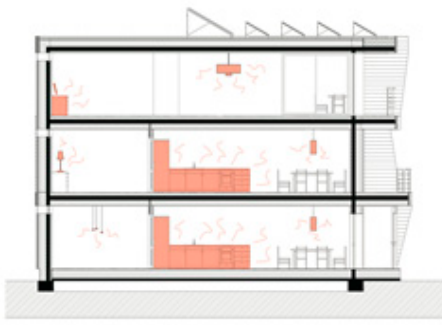

(b)

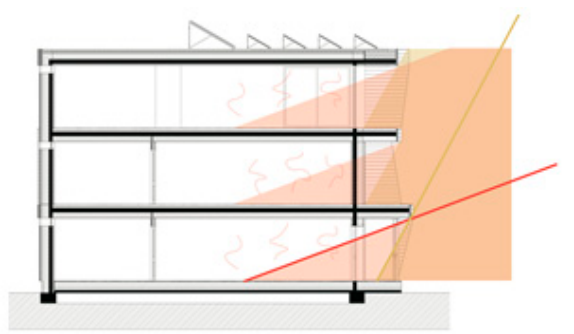

(c)

Figure 10. Internal gain model $(\mathbf{a}-\mathbf{c})$.

The Passive House Planning Package (PHPP) has been used as a design tool in the process of redesign. The package provides the architect and the engineer with instruments that are necessary for the design of a well-performing passive house [23]. Thus, the definition of PHPP needs some more clarification. In PHPP calculations, not only the heat losses, but also the heat gains and the thermal inertia can be determined. 
Through the PHPP worksheets, it is possible to define all heat gained from the sun, appliances, domestic hot water (DHW) distribution, and people as the users of the building. The latter internal gain is not a constant value in a flexible housing and has to be considered under different kinds of occupancy.

The first aspect noticed while working with the PHPP worksheet is the straight-forward organization of Microsoft Excel based spreadsheet. It is easy to insert all the different values for a building that is regular in plan or in elevation, however it is not the same way for a building that has an irregular shape or, such as in this case, a prototype that needs little adjustments in the architectural design in order to find the best shape for good indoor comfort. Another aspect that did not help in the design of a flexible home is the calculation of PHPP on a treated floor area. One of the main objectives of this project was to understand the difference in terms of the indoor comfort between the different kinds of configurations that a flexible design could allow; however, with the PHPP, only the comfort for the overall treated area of the whole building can be calculated. This aspect, for example, has importance for studying the overheating hours. The PHPP verification worksheet gives the frequency of overheating (Figure 11, central column, 7th row), which is the hour percentage per year in which the temperature exceeds $25^{\circ} \mathrm{C}$. Despite the fact that this result gives a good approximation of the average temperature, it does not give any information about the temperature distribution because there is no distinction between spaces in the north or south direction, or between the utilization of every room.

\section{Passive House Verification}

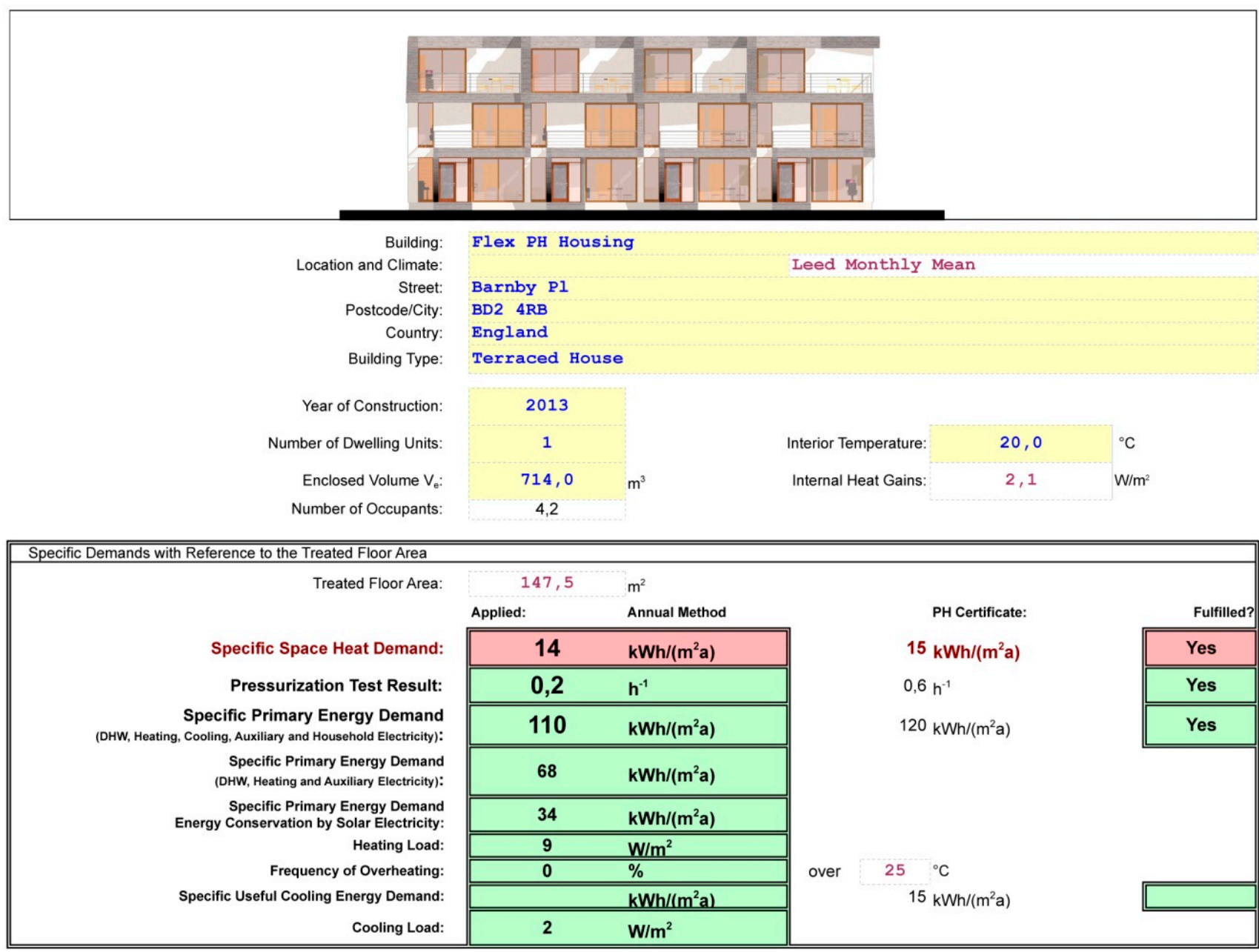

Figure 11. Passive House Planning Package (PHPP) verification worksheet. 
Energy performance evaluation is usually beneficial at the early stages of design; however, in this particular case, in redesigning of a social housing development, it is still an important factor that has to be considered in order to make the necessary provisions for achieving the best practice standards, i.e., low energy and low carbon $[25,26]$ for the future of sustainable housing. Hence, in recent years, applications of low and zero carbon technologies, and the adoption of renewable energy sources in domestic buildings has rapidly increased. On the one hand, it is equally important to design flexible houses in order to create provisions for the needs of future lifestyles, while also reducing the use of energy demand by maximizing the advantages of passive design and the use of low impact materials. This approach is essential nowadays and the benefit of passive design could allow indoor comfort with few renewable technologies. Passive design is not a supplement to architectural design, but it is rather part of the design process itself through an integrated approach to architectural and sustainable building design [27-29].

\subsection{Building Simulation}

In the study, DesignBuilder software has been used for conducting building simulation work [30]. The software package has integration with EnergyPlus, the US Department of Energy's (DOE) third generation dynamic building energy simulation engine for modeling building, heating, cooling, lighting, ventilating and other energy flows. This integration within DesignBuilder allow the user to carry out complete simulations without having to leave the interface, which is an excellent feature for practicing architects. The following table shows the necessary input information for building simulation analysis (Table 1).

Table 1. Building simulation input data for Heating, Ventilation, and Air Conditioning (HVAC), Domestic Hot Water (DHW), activity and construction.

\section{Compact HVAC}

HVAC systems is defined parametrically and modeled within EnergyPlus using Compact HVAC descriptions with a CAV (constant air volume)

\begin{tabular}{cc}
\hline \multicolumn{3}{c}{ Natural Ventilation } \\
\hline \multicolumn{2}{c}{ Natural Ventilation and infiltration air flow rates is calculated based on opening and crack, } \\
sizes, buoyancy, wind pressure and the activity schedules \\
\hline \multicolumn{2}{c}{ Mechanical Ventilation } \\
\hline $\begin{array}{c}\text { Mechanical ventilation utilized in the flexible housing design has an ac/h (air change per hour) rate of } \\
\text { 0.4, as required by the Passivhaus standard with an outside air definition method set for zone }\end{array}$ \\
\hline \multicolumn{2}{c}{ Fans } \\
\hline Night cycle control & Cycle on control zone \\
Fan placement & Blow through \\
Part-load power coefficients & Variable speed motor \\
Fan type & Intake \\
Pressure rise (pa) & 1000.0 \\
Total efficiency (\%) & 85.0 \\
Fan motor in air (\%) & 100.0 \\
Outside air definition method & Minimum fresh air (Per area) \\
Outside air mixing & Recirculation \\
Outside air control minimum flow type & Proportional \\
\hline
\end{tabular}


Table 1. Cont.

\begin{tabular}{|c|c|}
\hline \multicolumn{2}{|c|}{ Heat Recovery } \\
\hline Heat recovery type & Sensible \\
\hline Sensible Heat Recovery Effectiveness & 0.800 \\
\hline Heating set-point temperature & 15.00 \\
\hline \multicolumn{2}{|c|}{ Domestic Hot Water (DHW) } \\
\hline Type & Dedicated DHW boiler \\
\hline DHW CoP & 0.85 \\
\hline Fuel & Biomass \\
\hline \multicolumn{2}{|c|}{ Water Temperatures } \\
\hline Delivery temperature $\left({ }^{\circ} \mathrm{C}\right)$ & 65.00 \\
\hline Mains supply temperature $\left({ }^{\circ} \mathrm{C}\right)$ & 10.00 \\
\hline \multicolumn{2}{|c|}{ Activity } \\
\hline \multicolumn{2}{|c|}{$\begin{array}{l}\text { - Compact schedule has been used for occupancy, metabolic activity, openings of windows and doors, lighting, } \\
\text { and the schedules are based on data published in the UK's National Calculation Methodology (NCM)* } \\
\text { - The NCM for the EU's Energy Performance of Buildings Directive (EPBD) is defined by the Department } \\
\text { for Communities and Local Government (DCLG) [31]. }\end{array}$} \\
\hline \multicolumn{2}{|c|}{ Construction } \\
\hline $\begin{array}{l}\text { DesignBuilder uses construction components to } \\
\text { other opaque parts of the building envelope. Usi } \\
\text { have been defined for the building (e.g., extern } \\
\text { The same is true for windows and doors that ca }\end{array}$ & $\begin{array}{l}\text { of heat through walls, roofs, ground and } \\
\text { a, the physical properties of each element } \\
\text { rior wall, roof, floors and ground floor). } \\
\text { ell-provided library. }\end{array}$ \\
\hline
\end{tabular}

\section{Results and Discussions}

In this section, the analysis based on simulation studies has been presented. For the simulations, the following table shows several details of the selected housing unit (Table 2). As part of the analysis, a series of simulations has been carried out using DesignBuilder software considering the above input data (Table 1). One of the concerns was the overheating potential due to the type of construction used and in the case of Passivhaus standard adopted [23,32], i.e., super insulation, high levels of airtightness, and large levels of glazed south facade in the house design. Therefore, the study evaluated the internal comfort during one of the warmest weeks of the year in order to avoid likely overheating during summer periods.

Table 2. Selected housing unit information.

\begin{tabular}{cc}
\hline Dimensions & Meters (m) \\
\hline Width & 6.4 \\
Depth & 9.0 \\
Floor Height & 2.4 \\
Type of Unit & Mid-terraced House \\
Number of Floors & Ground +2 \\
Number of Bedrooms & 4 \\
Floor Area & $170 \mathrm{~m}^{2}$ \\
Climate Data & Leeds/Bradford (UK) \\
\hline
\end{tabular}


The following graphs are the results of an hourly internal comfort and temperature distributions for the living room on the ground floor from 6 to 13 July 2013 (Figures 12 and 13).
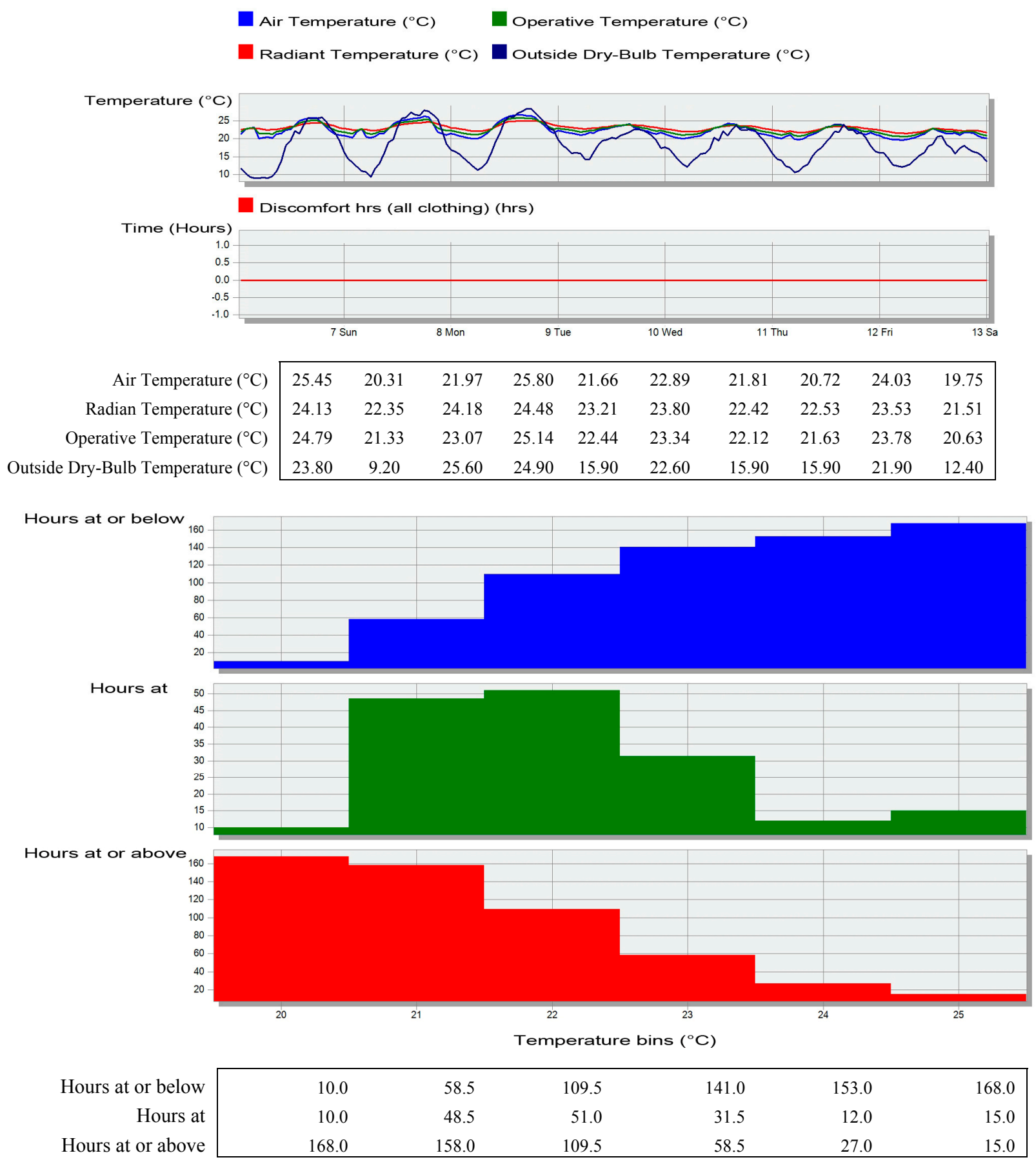

Figure 12. Typical summer week showing temperature and discomfort hours.

Again, same evaluation has been carried out for a typical winter week and the results have shown that the average temperature profile stays constant around $20^{\circ} \mathrm{C}$ due to heat recovery, insulation and solar gains (Figure 13). In a passive house design with the Passivhaus standard, there is no use of a space heating system, but there is a system that contains mechanical ventilation with heat recovery (MVHR) (Table 1). 

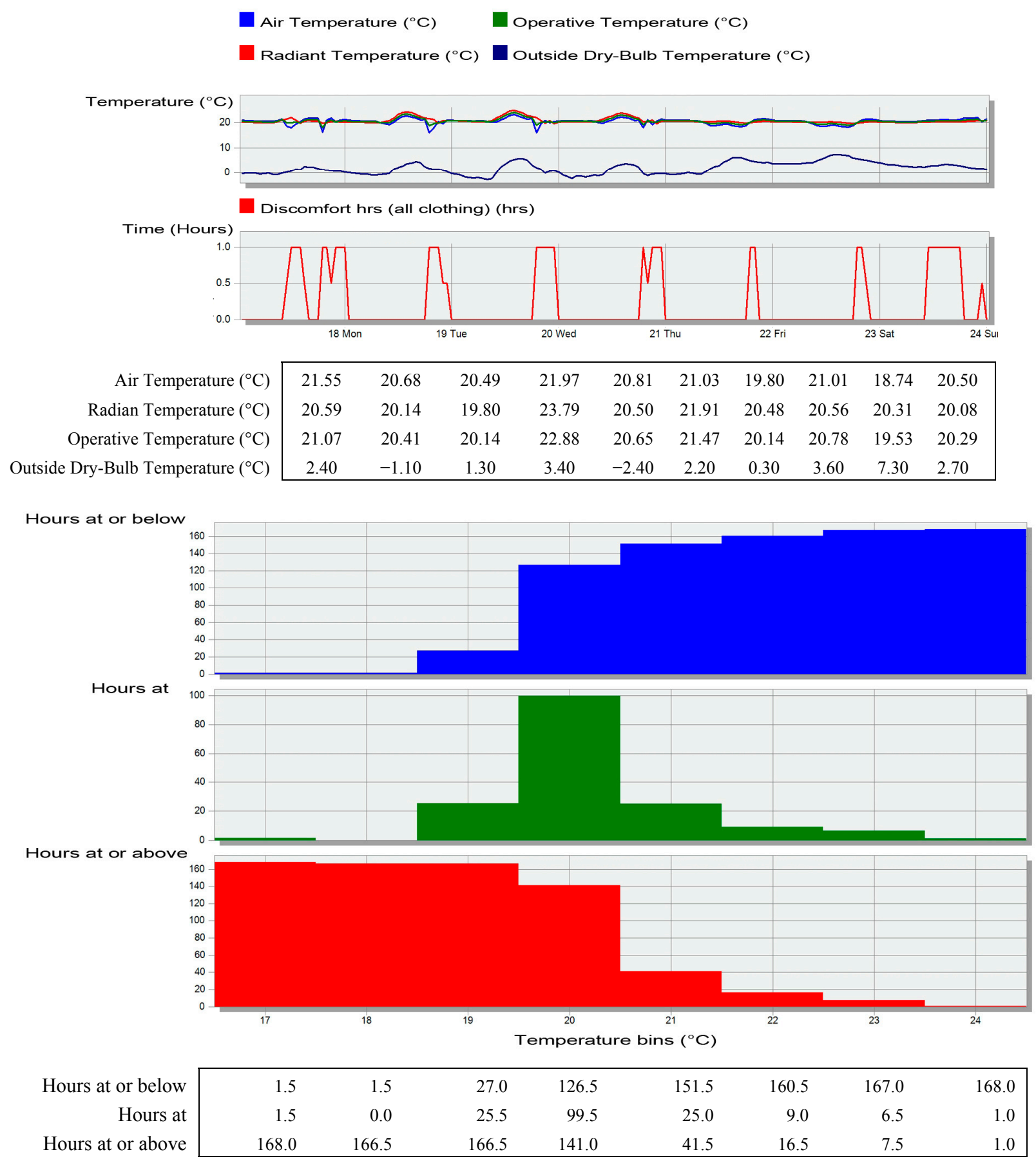

Figure 13. Typical winter week showing temperature and discomfort hours.

The following graph presents the total fuel breakdown listing different energy consumption for the redesigned flexible housing unit (Figure 14).

As the housing unit chosen has a floor area of $170 \mathrm{~m}^{2}$, to obtain the annual energy consumption and the associated carbon dioxide $\left(\mathrm{CO}_{2}\right)$ emissions, further calculations have been made to present the necessary values (Table 3). 


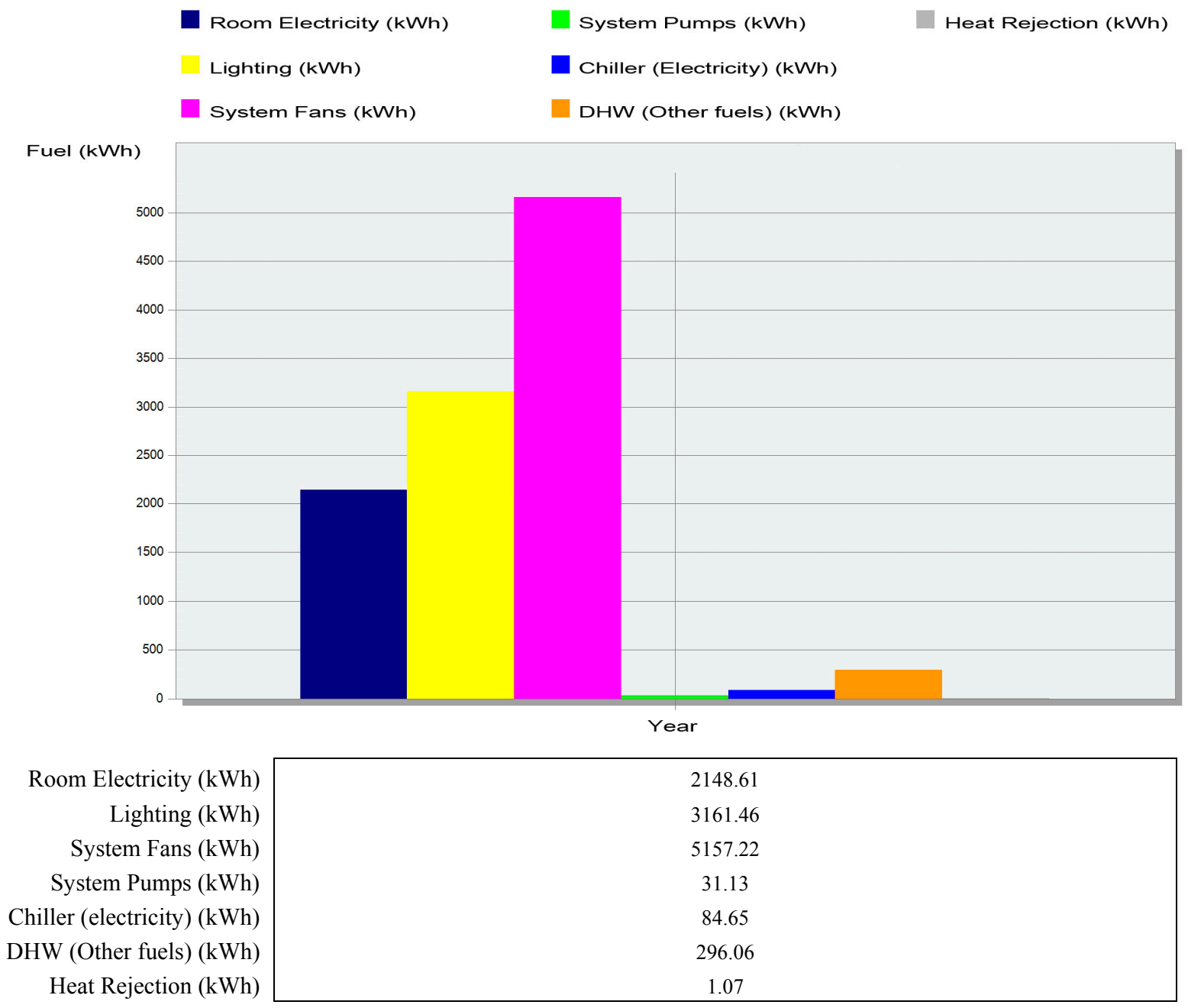

Figure 14. Fuel breakdown.

Table 3. Annual energy consumption and carbon emissions.

\begin{tabular}{cc}
\hline Total Energy Demand & Carbon Dioxide $\left(\mathbf{C O}_{\mathbf{2}}\right)$ Emission \\
\hline $10,880 \mathrm{kWh} /$ year & $7493 \mathrm{~kg} /$ year \\
$\mathbf{6 4} \mathrm{kWh} / \mathrm{m}^{2}$ & $\mathbf{4 4} \mathrm{kg} / \mathrm{m}^{2}$ \\
\hline
\end{tabular}

In order to demonstrate the benefits of simulation study findings for the case of redesign, it is important to compare against the measured consumption figures using the actual data recorded during post occupancy monitoring. The main reason for this is to cross-check the results with the existing social housing units (i.e., to compare with a real non-Passivhaus case where the units were designed to be energy efficient) and for the validity of the simulation studies. In this case, the following table presents the average measured energy consumption and the associated carbon dioxide emissions obtained from on-site monitoring between 2007 and 2009 (Table 4) [33]. As the existing housing unit floor area is $128 \mathrm{~m}^{2}$, the calculations are based on this value.

As can be seen from Tables 3 and 4, the simulated housing unit, i.e., the redesigned housing unit, has shown much better performance in terms of both the energy demand required and the carbon dioxide emitted. This, however, should be validated through real-time measurements in the redesigned units, particularly for checking against the accuracy of simulation studies. 
Table 4. Measured energy consumption and carbon dioxide emissions.

\begin{tabular}{cc}
\hline Total Energy Demand & Carbon Dioxide $\left(\mathbf{C O}_{2}\right)$ Emission \\
\hline $13,358 \mathrm{kWh} /$ year $*$ & $6833 \mathrm{~kg} /$ year \\
$\sim \mathbf{1 0 4} \mathrm{kWh} / \mathrm{m}^{2}$ & $\sim \mathbf{2 4 4} \mathrm{kg} / \mathrm{m}^{2}$ \\
\hline
\end{tabular}

* The measured data is based on an average usage during years 2007 to 2009 [33]. Note: Floor area for the same unit is $128 \mathrm{~m}^{2}$.

\section{Conclusions}

This paper attempts to describe an approach taken for different design phases to propose a new sustainable building, starting from the early stages of design to the building simulation component for performance evaluation. Collaboration between architects and engineers (i.e., aiding the design of a sustainable building; in this case a sustainable social housing unit) helped to find indoor comfort solutions by combining both structural and architectural features with integration of energy systems, where building simulation task played an important role.

PHPP has been very useful to acquire specific energy and heat demand analyses, and to verify whether the building achieves the Passivhaus standard. On the other hand, DesignBuilder can simulate indoor comfort conditions in greater detail, which makes it easier for the designer to understand the Passivhaus planning stages and how best to manage the results obtained through changing parameters and finding new solutions to fulfill all the requirements set to meet such a standard. Despite two software packages being used for various analyses in the study, both PHPP and DesignBuilder have many features, and provided similar results when compared to each other; thus, the use of both platforms helped to conduct a complete environmental analysis of the building designs, allowing cross-check of results.

The redesign of a terraced home has been a worthy challenge in terms of adopting flexibility in the building form and layout, as well as achieving the best practice energy efficiency standards. In this way, it was also useful to utilize building simulation and performance evaluation as means to help aid the building design, considering various important factors, such as the Passivhaus standard, concerns of overheating, and energy efficiency. Moreover, in real life situations, the occupant (i.e., the user) could still make a big difference in the way the energy is being used at home, even though the design could be a high performance case. However, it is still vital to get the design specification right and tested throughout the design process, which has been demonstrated in this study. Therefore, without undermining the energy conscious user/behavior to save energy at home, further studies should be undertaken and also related to the people variable, i.e., their behavior with attention paid to energy and environment, as a follow-up task.

Last but not least, this is a reminder for all practicing architects and design professionals to utilize the available building simulation platforms to aid their designs, or redesigns, at the early stages of design and throughout their design process. It is also equally important to aid the design with planning of passive design with the use of PHPP. Once more, integrated building design is not a myth, but a way of today's building design practice, and all professionals should work closely in full collaboration and integration, such as architecture and engineering, to help solving challenges of building science. 


\section{Acknowledgments}

The authors would like to thank the Accent Group Ltd. and their architects, the Goddard Wybor Practice (GWP) Ltd., and the Building Energy Analysis Unit (BEAU) at the University of Sheffield for providing the grounds and information to carry out this study. The project was supported by the EU's Lifelong Learning Programme (LLP).

\section{Author Contributions}

Hasim Altan designed the research. Nicola Gasperini performed the research and analyzed the data under supervision of Hasim Altan. Sam Moshaver provided academic support in flexible housing and Antonio Frattari provided academic advice throughout the research. All authors equally contributed in the writing of this paper. All authors read and approved the final manuscript.

\section{Conflicts of Interest}

The authors declare no conflict of interest.

\section{References}

1. Department of Energy and Climate Change (DECC). Digest of United Kingdom Energy Statistics. Available online: https://www.gov.uk/government/publications/energy-chapter-1-digest-of-unitedkingdom-energy-statistics-dukes (accessed on 10 March 2014).

2. Golland, A.; Blake, R. Housing Development: Theory, Process and Practice (Housing, Planning and Design Series); Routledge: London, UK, 2004.

3. Department for Communities and Local Government (DCLG). English Housing Survey: Housing Stock Report 2009. Available online: https:/www.gov.uk/government/uploads/system/uploads/ attachment_data/file/6725/1937212.pdf (accessed on 27 March 2015).

4. Office for National Statistics (ONS). Housing: Social Trends 41. Available online: http://www.ons.gov.uk/ (accessed on 15 April 2015).

5. Oxford. Oxford Dictionaries. Available online: http://www.oxforddictionaries.com/ (accessed on 24 March 2015).

6. Lelieveld, C.M.J.L.; Voorbij, A.I.M.; Poelman, W.A. Adaptable Architecture. In Building Stock Activation; Kitsutaka, Y., Ed.; TAIHEI Printing Co.: Tokyo, Japan, 2007; pp. 245-252.

7. Cuperus, Y. An introduction to Open Building. In Proceedings of the 9th Annual Conference of the International Group for Lean Construction (IGLC 2001), Singapore, 6-8 August 2001.

8. Altaş, N.E.; Özsoy, A. Spatial Adaptability and Flexibility as Parameters of User Satisfaction for Quality Housing. Build. Environ. 1998, 33, 315-323.

9. Narahara, T. Designing for Constant Change: An Adaptable Growth Model for Architecture. Int. J. Archit. Comput. 2010, 8, 29-40.

10. Kendall, S.; Teicher, J. Residential Open Buildings; E \& FN Spon: New York, NY, USA, 2010.

11. Forster, W. Housing in the 20th and 21st Centuries, Bilingual ed.; Prestel Publishing: New York, NY, USA, 2006. 
12. Leupen, B.; Heijine, R.; Zwol, J.V. Time Based Architecture; 010 Publishers: Rotterdam, The Netherlands, 2004.

13. Henket, H.J.; Heynen, H. Back from Utopia: The Challenge of the Modern Movement; 010 Publishers: Rotterdam, The Netherlands, 2002.

14. Lans, W.; Hofland, C. Flexibility, How to Accommodate Unknown Future Housing Requirements. In Proceedings of the 30th IAHS World Congress on Housing, Transforming Housing Environments through Design, Pretoria, South Africa, 27-30 September 2005.

15. Schneider, T.; Till, J. Flexible Housing: Opportunities and Limits. Archit. Res. Q. 2005, 9, 157-166.

16. Habraken, N.J.; Boekholt, J.T.; Dinjens, P.J.M.; Thijssen, A.P. Variations: The Systematic Design of Supports; MIT Press: Cambridge, MA, USA, 1976.

17. Cheng, M.-Y.; Lien, L.-C.; Tsai, M.; Chen, W.-N. Open-building Maintenance Management Using RFID Technology. In Proceedings of the 24th International Symposium on Automation and Robotics in Construction (ISARC 2007), Kochi, India, 19-21 September 2007.

18. Dluhosch, E. Flexibility/Variability and Programming. In Industrialization Forum; University of California: Berkeley, CA, USA, 1974; Volume 5, No 5.

19. Moshaver, S.; Altan, H. A Knowledge Model to Implement Home Working in Multi-tenant Housing. In Proceedings of the 15th International Union of Architects (UIA) World Congress, (DURBAN 2014), Architecture Otherwhere, Resilience-Ecology_Values, Durban, South Africa, 3-7 August 2014; p. 63.

20. Friedman, A. The Adaptable Home: Designing Homes for Change; McGraw-Hill: New York, NY, USA, 2002.

21. Altan, H. Sustainable Planning and Design: The Role of Environmental Analysis at the Initial Design Stages. In Proceedings of the 19th International Association for People-Environment Studies (IAPS) Conference, Alexandria, Egypt, 11-16 September 2006.

22. Muthesius, S. The English Terraced House; Yale University Press: New Haven, CT, USA, 1982.

23. Passivhaus Institut (PHI). Passive House Planning Package (PHPP) 2007: User Guide; PHI: Darmstadt, Germany, 2010.

24. Greenteg. Heat Flux Sensors and U-Value Kit for Building Physics. Available online: http://www.greenteg.com/heat-flux-sensor/u-value-measurement/ (accessed on 22 April 2015).

25. Energy Saving Trust (EST). Energy Efficiency Best Practice in Housing: Energy Efficient Refurbishment of Existing Housing; EST: London, UK, 2004.

26. Energy Saving Trust (EST). Domestic Low and Zero Carbon Technologies: Technical and Practical Integration in Housing; EST: London, UK, 2010.

27. Brophy, V.; Lewis, J.O. A Green Vitruvius: Principles and Practice of Sustainable Architectural Design, 2nd ed.; Earthscan: London, UK, 2011.

28. Keeler, M.; Burke, B. Fundamentals of Integrated Design for Sustainable Building, 1st ed.; US Green Building Council: NJ, USA, 2009.

29. Yudelson, J. Green Building through Integrated Design; McGraw-Hill Professional: New York, NY, USA, 2009.

30. DesignBuilder. DesignBuilder Software Energy Simulation Package. Available online: http://www.designbuilder.co.uk/ (accessed on 2 August 2013). 
31. BRE. National Calculation Method (NCM). Available online: http://www.ncm.bre.co.uk/ (accessed on 8 August 2011).

32. Uffelen, C.V. Passive Houses: Energy Efficient Homes; Braun Publishing AG: Salenstein, Switzerland, 2012.

33. Altan, H. Accent Homes Project: Post-Occupancy Monitoring Internal Report; Sheffield University: Sheffield, UK, 2010.

(C) 2015 by the authors; licensee MDPI, Basel, Switzerland. This article is an open access article distributed under the terms and conditions of the Creative Commons Attribution license (http://creativecommons.org/licenses/by/4.0/). 